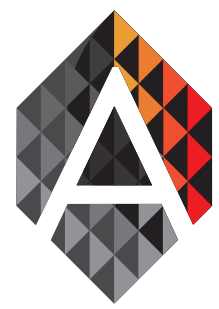

ADCAIJ: Advances in Distributed Computing and Articial Intelligence Journal Regular Issue, Vol. 6 N. 1 (2017), 21-29 eISSN: $2255-2863$

DOI: http://dx.doi.org/10.14201/ADCAIJ2017612129

\author{
XX Ibero-American Congress of It and Law \\ Salamanca (Spain), 19-21 October 2016
}

\title{
Freedom of Expression, Right to Information, Personal Data and the Internet in the view of the Inter-American System of Human Rights
}

\author{
Silvia Susana Toscano ${ }^{\mathrm{a}}$ \\ ${ }^{a}$ Dean of the School of Legal and Social Sciences, Fundación UADE (Universidad Argentina de la Empresa)
}

\begin{tabular}{|c|c|}
\hline KEYWORDS & ABSTRACT \\
\hline $\begin{array}{l}\text { Freedom of } \\
\text { expression; } \\
\text { Right to } \\
\text { information; } \\
\text { Data and internet } \\
\text { in the view of } \\
\text { Inter-American } \\
\text { System of Human } \\
\text { Rights }\end{array}$ & $\begin{array}{l}\text { The Inter-American System of Protection of Human Rights is composed of microsys- } \\
\text { tems, like the freedom of expression, the right to information and the protection of } \\
\text { privacy and of personal data, among others. These rights interrelate and form the } \\
\text { standards of the Inter-American system, in accordance with the UN system, to devel- } \\
\text { op these liberties, and to keep the constant balance of these rights in conflict. All of } \\
\text { this enhanced by a dynamic and growing massiveness, like the internet and by a new } \\
\text { paradigm in which the freedom of expression and the right to information is included: } \\
\text { a postmodern society characterized by a «democratization» of connectivity, a multi- } \\
\text { directional transmission of the information and a dichotomy between what is public } \\
\text { or private. } \\
\text { Freedom of expression is developed in both of its two dimensions: individual or } \\
\text { collective. When we talk about its individual dimension, we mean the right of each } \\
\text { person to express his ideas, thoughts and beliefs aiming at unidirectional, bidirection- } \\
\text { al or multidirectional communication. The collective or social dimension refers to the } \\
\text { right of a person to receive any type of information, to know the thoughts, ideas and } \\
\text { information of others and have free access to them. } \\
\text { Both dimensions are equally important and are interdependent, thus it is import- } \\
\text { ant to protect them simultaneously. New communication technologies have altered the } \\
\text { previous system, and the individual dimension of freedom of expression breaks into } \\
\text { public debate on the democratization of internet access and its social dimension due } \\
\text { to the feasibility a multidirectional communication impossible to conceive in any other } \\
\text { technological paradigm entails. The protection scheme of freedom of expression of the }\end{array}$ \\
\hline
\end{tabular}

Eduardo Munera, Jose-Luis Poza-Lujan, Juan-Luis PosadasYagüe, Jose-Enrique Simó-Ten, and Francisco Blanes Integrating Smart Resources in ROS-based systems to distribute services
ADCAIJ: Advances in Distributed Computing and Articial Intelligence Journal Regular Issue, Vol. 6 N. 1 (2017), 21-29 eISSN: 2255-2863 - http://adcaij.usal.es (c) Ediciones Universidad de Salamanca - CC BY-NC-ND 
Inter-American System is particularly strong as it specifically prohibits prior censorship and rules sanctions and very strict restrictions in relation to discrimination, advocacy of war, violence and hatred.

This characteristic enriches the analysis of content regulation and the responsibility of internet intermediaries whenever honour, reputation and privacy are impaired. The applied standards and statements that nourish in the American Convention on Human Rights guarantee the reasonableness, appropriateness and proportionality of any measure assuring freedom of expression and human dignity.

Article 13. Freedom of Thought and Expression. American Convention on Human Rights, San José de Costa Rica, 22 November 1969.

1. Every person has the right to freedom of thought and expression. This right includes freedom to seek, receive, and disseminate information and ideas of any kind, regardless of frontiers, either orally, in writing, in print, in the form of art, or through any other means of one's choice.

2. The exercise of the right set forth in the foregoing paragraph shall not be subject to prior censorship but shall be subject to subsequent liabilities that shall be expressly established by law to the extent necessary to ensure: a) the respect for the right or reputation of others; or b) the protection of national security, public order or public health or morality.

3. The right of expression shall not be restricted by indirect methods or means, such as the abuse of governmental or private controls over newsprint, radio broadcasting frequencies, or equipment used in the dissemination of information, or by any other means tending to impede the communication and circulation of ideas and opinions.

4. Notwithstanding the provisions, set forth in paragraph 2 above, public entertainment may be subject by law to prior censorship for the sole purpose of regulating access to them for the moral protection of childhood and adolescence.

5. Any propaganda in favor of war or any advocacy of national, racial or religious hatred that constitutes incitement to illegal violence or any other similar act against any person or group of persons on any grounds, including those of race, color, religion, language or national origin shall be considered as offences and punishable by law.

\section{Introduction}

We decided to begin this paper with the transcription of Article 13 of the American Convention on Human Rights (1969), because its text sums up the title of our paper as well as the effect of the existing conflict between the human rights mentioned in it, in a global and technological world, and under the watchful eye of a protective system, the Inter-American System of Human Rights Protection, which shelters and strengthens them in each state, both at regional and domestic level.

Due to the time the Convention was created, the internet was not considered in it. Unquestionably, the Convention's regulations may be applied to it, since its spirit makes reference to the content of law and to its dissemination by means of a media plurality, considering that the internet opens exclusivity which was previously held only by those persons having access to the then known media.

Each freedom constitutes a microsystem that, as such, has the autonomy granted by the specificity of the rules, though all of them are functionally related, so it is impossible to conceive them in isolation but as part of a system with general rules that give certainty, completeness and predictability. That is the Inter-American System of Human Rights Protection.

Eduardo Munera, Jose-Luis Poza-Lujan, Juan-Luis PosadasYagüe, Jose-Enrique Simó-Ten, and Francisco Blanes Integrating Smart Resources in ROS-based systems to distribute services
ADCAIJ: Advances in Distributed Computing and Articial Intelligence Journal Regular Issue, Vol. 6 N. 1 (2017), 21-29 elSSN: 2255-2863 - http://adcaij.usal.es (c) Ediciones Universidad de Salamanca - CC BY-NC-ND 
It may be said that we are in the presence of microsystems that must interrelate and, in doing so, they form the Inter-American system standards, in line with the UN ones, to develop these freedoms and to keep the constant balance of these rights in conflict. All of this boosted by a dynamic platform and growing massiveness as it is the Internet.

Both Article 13 and the search of a difficult balance between the freedoms that form these microsystems compel us to go deep into one of them: the freedom of expression to coordinate its relation with the rest of them always with the aim to achieve a balance that will assure individuals the guarantee and respect for their rights.

\section{Freedom of expression in the Inter-American System}

A detailed analysis of the main documents of the Organization of American States (OAS) and other declarations, as well as, the jurisprudence of the International Court of Human Rights point out the existence of an exceptional protective system for the freedom of expression even more intensive than in compared systems, like the European Union.

Indeed, Article $\mathrm{IV}^{1}$ of the American Declaration and Article $43^{2}$ of the Inter-American Democratic Charter, among others, are included in the abovementioned Article 13, designing a regulation network that guarantees the specific prohibition of prior censorship and a minimum system of restrictions to the freedom of thought.

The referred documents reaffirm the freedom of opinion by any means. Likewise, Article $4^{\circ}$ of the Inter-American Democratic Charter highlights the importance of «...transparency in governmental activities, probity, responsible public administration on the part of governments, respect for social rights, and freedom of expression and of the press...» as essential components of the exercise of democracy.

It is possible that said strength bases on the own political growth of America and the need of placing freedom of expression at a higher and privileged position within the liberties of any democratic state. The Inter-American Court of Human Rights stated that «... freedom of expression in an indispensable requirement for the very existence of a democratic society... $\rangle^{3}$.

Democracy and authoritarianism together with the successive shifting with military regimes in most of the Latin American countries, especially Central and South America, could be the basis for this extreme protection of the freedom of expression.

Although freedom of expression has been the object of several analyses related to press freedom, it is important to point out that it is a broader concept and it is related to the right to information. In this sense, we are interested in its discussion.

Freedom of expression is developed in its two dimensions: individual and collective. When we talk about the individual dimension, we mean the right of every person to express his ideas, thoughts and beliefs with the aim to communicate them unidirectionally, bidirectionally or multidirectionally.

The collective or social dimension consists in the right of every person to receive any type of information, to know the opinion, ideas and information of others, and to have free access to them.

Both dimensions are equally important and are interdependent, thus it is important to protect them simultaneously. The new communication technologies have altered the previous system and the individual dimension of the freedom of expression breaks into the public debate on the democratization of internet access and its social dimension, due to the feasibility a multidirectional communication impossible to conceive in any other technological paradigm entails. Hence, the importance the right to information acquires with internet access (Castilla Juarez, 2011).

1. American Declaration of the Rights and Duties of Man approved in the Ninth International Conference of American States, Bogotá, Colombia (1948). Article IV: «Any person has the right to freedom of investigation, opinion, expression and dissemination of thoughts by any means».

2. Inter-American Democratic Charter approved in the first OAS regular session held on September 11, 2001, Article IV.

3. IACHR. «n.d.» Compulsory Membership in an Association for the practice of Journalism, Advisory Opinion AO-5/85 Series A, $\mathrm{N}^{\circ} 5$, par. 70 .

Eduardo Munera, Jose-Luis Poza-Lujan, Juan-Luis PosadasYagüe, Jose-Enrique Simó-Ten, and Francisco Blanes Integrating Smart Resources in ROS-based systems to distribute services
ADCAIJ: Advances in Distributed Computing and Articial Intelligence Journal Regular Issue, Vol. 6 N. 1 (2017), 21-29 eISSN: 2255-2863 - http://adcaij.usal.es (c) Ediciones Universidad de Salamanca - CC BY-NC-ND 
The risk to impair other rights of the same hierarchy, like the right to honour, reputation, identity and intimacy, is present in both aspects. This is the public debate that arises with the internet massive character we referred to ut supra.

There are no expressions that are more protected than others since this would depart from the concept of freedom of expression the Inter-American System has. This system restricts a limited number of possible interferences and specifically prohibits prior censorship or indirect mechanisms of censorship pursuant to Article 13, subsection 2 of the American Convention on Human Rights. Notwithstanding, the Inter-American Court of Human Rights established that expressions related to matters of public interest as well as those referred to public officers on duty, or candidates to fill public positions must enjoy a wide protection to promote the participation of individuals in public office 4 .

On the other hand, as per article 13, subsection 5 of the Convention, the restrictions of the Inter-American System consider any discriminatory content, advocacy of war or otherwise, which may incite hatred and violence. The extent of the definition of these contents becomes important and it is here where internet risks are verified due to its exponential growth, the viralisation of these expressions and the way they affect honour, privacy, identity and reputation, among other rights.

We have pointed out that the treatment of freedom of expression in its two dimensions: individual and social, infers the creation of a massive and multidirectional dialogue in the network, the internet. The statements of some individuals are known by others, and this implies the exercise of another right, the right to information which, in some cases, conflicts with and restricts the freedom of expression ${ }^{5}$.

\section{The right to information in the Inter-American system}

The right to information is considered a natural and implied right of human beings at international and local levels of each democratic state.

It must be understood that information is intangible property protected by law not only for its intrinsic value but also for the fact that the access to this right makes the enjoyment of other rights possible (Abramovich et al., 2000).

The legal recognition of the right to information as an individual right makes its way raising in the States important legal problems like the institutionalisation of the legal guarantees which allow their protection.

Many international agreements, treaties and statements refer to the right to information. Only to mention one of them, Resolution 59 of the General Assembly of the United Nations, adopted on December 14 1946, when the International conference of the Right to Information was summoned, stated: «...freedom of information is a fundamental human right and the touchstone of all the freedoms to which the United Nations is consecrated. [...] Freedom of information requires, as an indispensable element, the willingness and capacity to employ its privileges without abuse» ${ }^{6}$.

Freedom of information presupposes an independent access to it and an assumption for the exercise of other rights. To guarantee, properly, the right of citizens to have access to information, the theoretical framework of this right must be fully understood. The importance of assigning this characteristic to the right to information derives from this, since it would not only be part of the typical notions of human rights, i.e. universal, absolute, inalienable and permanent, but also acknowledged by law under the criteria of justice and legality. Consequently, its positivization as guarantee of the acceptance of legal and political institutions becomes important.

Thus, the general right to information turns into the legal claim to have access to it, becoming in a claim legally protected and guaranteed.

4. IACHR Conf., Case: Kimel v. Argentina. Decision on the merits, remedies and legal costs and expenses. Judgment rendered on May 2, 2008. Series C. No. 177, par. 86-88; IACHR, Case: Claude Reyes et al v. Chile. Decision on the merits, remedies and legal costs and expenses. Judgment rendered on September 19, 2006. Series C. No. 151, par. 87.

5. OAS. (2013). Libertad de Expresión e Internet [Freedom of Expression and the Internet] (official documents; Ser. L). ISBN 978-0-8270-6134-7.

6. Retrieved May 27, 2016, from www.un.org/spanish/documents/ga/res/1/ares1.htm.

Eduardo Munera, Jose-Luis Poza-Lujan, Juan-Luis PosadasYagüe, Jose-Enrique Simó-Ten, and Francisco Blanes Integrating Smart Resources in ROS-based systems to distribute services
ADCAIJ: Advances in Distributed Computing and Articial Intelligence Journal Regular Issue, Vol. 6 N. 1 (2017), 21-29 eISSN: 2255-2863 - http://adcaij.usal.es (c) Ediciones Universidad de Salamanca - CC BY-NC-ND 
Information is a fundamental constituent of democracy and an important human right since the right to information enhances and allows the exercise of the other rights.

Under the same point of view, the Inter-American Court of Human Rights found in the case «Marcel Claude Reyes et al v. Chile» ${ }^{7}$ that the access to information under the power of the Government is a basic human right. We only need to mention the following paragraph: «... Court's case law has dealt extensively with the right to freedom of thought and expression embodied in Article 13 of the Convention, by describing its individual and social dimensions, from which a series of rights protected by this article arose... In this regard, the Court has established that, according to the protection granted by the American Convention, the right to freedom of thought and expression includes «not only the right and freedom to express one's thoughts, but also the right and freedom to seek, receive and disseminate information and ideas of all kinds».

Based on its background, the Organization of American States approved the Model Inter-American Law on Access to Information held by the state, reaffirming that access to information is a fundamental human right and a vital requirement for all democratic societies ${ }^{8}$.

Because today, information is found mainly on the internet, it is necessary to contextualize this right. Therefore, the General Assembly of the United Nations (UN) declared internet access as a highly protected human right. The UN requires its Member States to provide an accessible and affordable service for everyone, and considers it a priority to ensure internet access to all citizens ${ }^{9}$.

Internet «...not only allows individuals to exercise their right to opinion and expression, but also forms part of their human rights and promotes the access of society as a whole...» ${ }^{10}$.

Freedom of expression and the right to information are included in this new paradigm: a postmodern society characterized by a «democratization» of connectivity, and a multidirectional transmission of the information.

Both are the result of a technological convergence through which it is possible to provide a general offer of services and the dissemination of information in real time, which play a role in the necessary changes for this information society to be the centre of the political, social, economic and cultural transformation that give them the content and their meaning. This multidirectional communication or communication network, as their names imply, go in all directions, and an indefinite number of persons participate as senders and receivers at the same time. In this type of communication, feedback is unlimited and gives rise to knowledge and opinion creating new sources of information.

In this scenario, it is necessary to highlight the role of privacy and of personal data. Since internet contents disseminate very quickly and increase exponentially, deriving in a viral effect causing that an event or comment even challenges the author, who loses the control of their dissemination, this communication strengthens and becomes publicly visible.

\section{Personal data protection in the Inter-American System}

In this occasion, we will only refer to this right in relation to the right to information and freedom of expression. Even though these principles have been searching for balance during the years, the evolution of technology has had, with greater emphasis, an impact on the need to find a framework of respect in which they may develop without subjugating one to the other.

Since the elaboration of doctrine in the United States by the jurists, Warren and Brandeis (1890), in their hermeneutics on the right to privacy (Warren et al.,1890), the concept of privacy is developed as a right to

7. IACHR. Case: Claude Reyes et al v. Chile. Decision on the merits, remedies and legal costs and expenses. Judgment rendered on September 19, 2006. www.corteidh.or.cr/casos.cfm?idCaso=245 [retrieved on May 27, 2016].

8. AG/RES. 2607 (XL-O/10), Model Inter-American Law on access to information held by the State approved by the fourth General Assembly held on June 8, 2010.

9. Cf. UN Human Rights Council (2012). The promotion, protection and enjoyment of Human Rights on the Internet. A/ HRC/20/L.13.

10. AG/RES.1932 (XXXIII-O/03) Access to Public Information: Strengthening Democracy. Retrieved May 30, 2016, from www.oas.org.

Eduardo Munera, Jose-Luis Poza-Lujan, Juan-Luis PosadasYagüe, Jose-Enrique Simó-Ten, and Francisco Blanes Integrating Smart Resources in ROS-based systems to distribute services
ADCAIJ: Advances in Distributed Computing and Articial Intelligence Journal Regular Issue, Vol. 6 N. 1 (2017), 21-29 eISSN: 2255-2863 - http://adcaij.usal.es (c) Ediciones Universidad de Salamanca - CC BY-NC-ND 
solitude, secrecy and isolation. The aforementioned writers referred to «the right to be let alone», not based on the right of property but on the privilege of freedom of individuals.

The American conception of privacy means the respect for that part of intimacy that neither individuals nor the State may put pressure on or invade to control a person. The European doctrine has the same understanding but develops it under a more complex and liberal conception. The truth is that whatever the conception is, this principle has developed embracing unthinkable areas specially promoted by technological advances.

The majority of international treaties and documents acknowledge the expressly mentioned right in the Universal Declaration of Human Rights (1948); the American Declaration of the Rights and Duties of Man (1948); the European Convention for the Protection of Human Rights (1968) and the American Convention on Human Rights (Pact of San José de Costa Rica) (1969), article 11 ${ }^{11}$, among others.

This article enshrines the respect to honour and reputation, and protects individuals of any arbitrary interference in private life, this being a wide concept that the Inter-American Court of Human Rights has interpreted in several judgments ${ }^{12}$.

Personal data are an aspect of privacy and the object of specific international and local rules. At international level, it is worth mentioning the UN International Conference on Human Rights (Teheran, 1968), the regulations of the European Council (1973 \& 1974) and the Strasbourg Convention on the Protection of Individuals with respect to Automatic Processing of Personal Data (1981).

Considering that the foundation of these laws is the so called «principle of informative self-determination», it follows that the guiding principles are the consent and the quality of the data, understanding it under the wide and comprehensive criteria of the confidentiality of sensitive data, their end, certainty and security, among others.

To reconcile the right to access and the protection of personal data does not mean «... a priori a true collision, dispute or conflict. Thus, tension should not be addressed to a prior jusphilosophical reality, but rather it is necessary that the competent administrative authorities, or the authorities with jurisdictional or quasi-jurisdictional powers in the subject matter, solve the issue harmoniously ad casum» ${ }^{13}$.

Therefore, all the laws protecting personal data consider exceptions to consent, which is the basic and legitimate reason for the informative self-determination. Moreover, they grant the holder the right to access, correct, update and privacy both in the collection and the assignment of them. This informative self-determination, also known as internet freedom, allows the individual to exclude third parties from knowing about his privacy or his personal data even in this information society.

On top of that, the State reserves the right to establish the confidentiality of certain information in which national security and the interest of the public or third parties, whose privacy must protect, is involved.

\section{The new privacy paradigm in its relation to the right to information and freedom of expression}

Before concluding, we would like to analyse the current situation of privacy and personal data in agreement with the freedoms previously discussed from the point of view of another characteristic of this postmodern society: the dichotomy between what is public or private.

These two concepts have always gone hand in hand with society but with different conceptions. In Rome, the recognition of the free man was public while a very restricted area both in scope and in who could enjoy it

11. American Convention on Human Rights «Article 11. Right to Privacy 1. Everyone has the right to have his honor respected and his dignity recognized. 2. No one may be the object of arbitrary or abusive interference with his private life, his family, his home, or his correspondence, or of unlawful attacks on his honor or reputation. 3. Everyone has the right to the protection of the law against such interference or attacks»».

12. IACHR. Case Escher et al v. Brazil. Interpretation of the Judgment on pretrial motions, decision upon the merits, remedies and legal costs and expenses. Judgment rendered on November 20, 2009. Series C No. 208.

13. For further information, see Ibero-American Data Protection Network, 2005. The access to public information and protection of personal data. Ibero-American Data Protection Network. Huixquilucan, Mexico.

Eduardo Munera, Jose-Luis Poza-Lujan, Juan-Luis PosadasYagüe, Jose-Enrique Simó-Ten, and Francisco Blanes Integrating Smart Resources in ROS-based systems

to distribute services
ADCAIJ: Advances in Distributed Computing and Articial Intelligence Journal Regular Issue, Vol. 6 N. 1 (2017), 21-29 elSSN: 2255-2863 - http://adcaij.usal.es (c) Ediciones Universidad de Salamanca - CC BY-NC-ND 
was private. Modern times marked another difference since privacy began to intertwine with the principle of property and the possibility to delimit an area that restricted third parties' acts, even those of the State.

Bobbio (2003) stated that what is public or private are representations of the society, which have gone hand in hand with the development of capitalism and the more global process of modernity. «... Based on the imaginary dichotomy, social systems and regulations were repeated and organized, and spaces of competence for economic, political and cultural activities were defined...».

The truth is that both terms of this dichotomy are mutually conditioned, since they are constantly claiming one another. Today, the society characterizes by the «publicization» of private life.

What is public or private began to be defined and what is private began to socialize through different institutions. Today, the internet and the social networks are the arena in which individuals exercise the power to determine what part of their private life they decide to make public. This new way of communication that internet raises with the access to information in real time and with the social networks, among other forms, represent a new way for persons to interact creating groups of reference. Moreover, this publicization is deepened due to the need to show oneself and belong, elements that emphasize this weak limit between what is public or private.

Although the individuals in this postmodern society support the flag of privacy, they have not found yet the balance between being a global citizen and defining a private space for their individual development. Communication media and internet intermediaries have a great responsibility in the difficult delimitation between what is public or private. In the current society, the limit that separates what is public or private is vague exactly because there are social communication media and information professionals.

Our own assessment of social and private life dilutes and most of the times, the public arena is externally defined like the assumption that we are labeled in the social network, our photographs are uploaded and we do not have any control over them. Companies go on developing technologies like privacy by default becoming the guardians of this privacy that individuals seem to neglect. The internet of things, Big Data, cloud computing are technological tools which provide us services, but the control of our personal data is not completely guaranteed.

This new paradigm of privacy is strengthened by the flow of information as a result of the freedom of expression and of information which broke into public debate and is favoured by a technology more and more attractive and facilitating.

\section{Conclusions}

With the paradigm we mentioned and the technological convergence favoured by the democratization of internet access and the multidirectional communication already described, the concepts of freedom of expression, the right to information and protection of privacy have a different meaning and require a constant interpretation to achieve a balance that reduces the conflict arising between these principles.

One of the interpretation criteria that must be analysed in this context is the regulation of the contents and the responsibility of internet intermediaries according to the Inter-American System.

We made reference to the extraordinary protection given to freedom of expression and the specific prohibition of prior censorship in terms of the American Convention on Human Rights, Article 13.

In this sense, the Office of the Special Rapporteur for Freedom of Expression of the Inter-American Convention on Human Rights, in its Joint Declaration on Freedom of expression and the Internet ${ }^{14}$, stated it is important that «... any regulation made must be the result of the dialogue of all the players, and keep the basic characteristics of the original environment, enhancing its democratizing capacity and promoting universal access without discrimination...». This in reference to the neutral environment the internet assumes to unfold the potential freedom of expression.

Through all the documents abovementioned, it is pointed out that restrictions only may be founded on those exceptions admitted by the American Convention and that meet the criteria of necessity, appropriateness and

14. IACHR. 2013. Libertad de Expresión e Internet [Freedom of expression and the Internet], p. 5 para. 11. Retrieved May 30, 2016, from www.oas.org/es/cidh/expresion/docs/informes/2014_04_08_internet_web.pdf. 19 Retrieved May 30, 2016, from www./documents-dds-ny.un.org.

Eduardo Munera, Jose-Luis Poza-Lujan, Juan-Luis PosadasYagüe, Jose-Enrique Simó-Ten, and Francisco Blanes Integrating Smart Resources in ROS-based systems to distribute services
ADCAIJ: Advances in Distributed Computing and Articial Intelligence Journal Regular Issue, Vol. 6 N. 1 (2017), 21-29 elSSN: 2255-2863 - http://adcaij.usal.es (c) Ediciones Universidad de Salamanca - CC BY-NC-ND 
proportionality. Similarly, Frank La Rue, UN rapporteur of the Office of the Special Rapporteur for Freedom of Expression, in the 2013 report $^{19}$, stated a category of contents capable of being restricted: 1) Expressions considered criminal offences under international law and that, in the Budapest Convention on Cybercrimes (2008), the majority of the countries agreed to sanction and co-operate in their detection, investigation and prosecution. Some examples of these are: child pornography; statements in support of terrorism; discrimination; incitement to commit genocide; terrorism, among others; 2) expressions not considered criminal offences but that may be subject to civil liability; and 3) those expressions not falling under the category of criminal offences or torts but which affect the rules of civility, tolerance, coexistence and respect of others.

Therefore, the regulation of contents or internet intermediaries as prior censors are unacceptable in the paradigm described in this postmodern society, which is characterized by the breaking into of the individual dimension of freedom of expression in the public debate, the «publicizing» of private life and the freedom of information favoured by a multidirectional flow.

There is the risk that a different interpretation would subject and oblige private systems to eliminate a statement, opinion or belief undermining the neutral character of the internet and that assures us the respect for the liberties. In case a content infringes said freedoms, the pertinent judge or administrative authority must intervene in order to respect the impartiality principle.

The Inter-American System of Protection of Human Rights has laid the foundations and standards to guarantee a remarkable protection of the freedom of expression and information in the internet observing the restrictions set forth in the Inter-American Convention. These rules guarantee human beings the right to honour, privacy and identity without distorting the massiveness and neutrality of the internet in accordance with the permanent search for a balance among these liberties.

\section{References}

Abramovich, V., \& Courtis, C. (2000). El acceso a la información como derecho [Access to information as a right], Anuario de Derecho de la Comunicación, Año 1 Vol. I, Ed. Siglo XXI, Bs. As.

Bobbio, N. (2003). State, Government and Society. pp. 12 et seq. Mexico: Economic Culture Fund.

Castilla Juarez, C. (2011). Libertad de expresión y derecho de acceso a la información en el sistema interamericano de derechos humanos [Freedom of expression and the right to Access to information in the Inter-American system of human rights]. Comisión Interamericana de Derechos Humanos [Inter-American Commission on Human Rights]. Mexico. ISBN 978-607-8211-06-7 p. 24 et seq.

Warren, S., y Brandeis, L. (1890). The right to privacy. Harvard Law Review, Vol. IV, № 5.

\section{Bibliography}

Garcia Ramirez, S. \& Gonza, A. (2007). La libertad de expresión en la jurisprudencia de la Corte Interamericana de Derechos Humanos [Freedom of expression in the case law of the Inter-American Court of Human Rights]. ( $1^{\circ}$ ed.). Costa Rica.

Mendel, T. (2003). The right to information in Latin America. A comparative legal survey. UNESCO Regional Office for Communication and IT.

Solove, J. D. \& Rotemberg, M. (2003). Information Privacy Law. New York: Aspen Publishers.

\section{Articles, papers and reports}

Ayala Corao, C., 2001. Reflexiones sobre el futuro del sistema interamericano de derechos humanos [Reflections on the future of the Inter-American System of Human Rights]. At: Revista IIDH, Nos. 30-31, special issue. San José. IIDH.

Eduardo Munera, Jose-Luis Poza-Lujan, Juan-Luis PosadasYagüe, Jose-Enrique Simó-Ten, and Francisco Blanes Integrating Smart Resources in ROS-based systems

to distribute services
ADCAIJ: Advances in Distributed Computing and Articial Intelligence Journal Regular Issue, Vol. 6 N. 1 (2017), 21-29 eISSN: 2255-2863 - http://adcaij.usal.es (c) Ediciones Universidad de Salamanca - CC BY-NC-ND 
Inter-American Commission on Human Rights (2015). Annual report of the Special Rapporteur on freedom of expression. Annual report of the Inter-American Commission of Human Rights, 2015, vol. 2 / Edison Lanza, Special Rapporteur on Freedom of Expression.

Inter-American Commission on Human Rights (2013). Freedom of Expression and the Internet.

Red Iberoamericana de Protección de Datos Personales (2005). El acceso a la información pública y la protección de los datos personales [The access to public information and protection to personal data]. Red Iberoamericana de Protección de Datos Personales. Huixquilucan, Mexico.

\section{Consulted websites}

Asociación por los Derechos Civiles. «n.d.» Retrieved [fecha], from http://www.adc.org.ar.

Biblioteca jurídica virtual. «n.d.» Retrieved [fecha], from www.bibliotecajuridicavirtual.org.

Biblioteca jurídica El Dial. «n.d.» Retrieved [fecha], from http://www.eldial.com.

Centro de Implementación de Políticas Públicas para la Equidad y el Crecimiento. «n.d.» Retrieved [fecha], from http://www.cippec.org/nuevo/.

Centro Latinoamericano de Administración para el Desarrollo (CLAD). «n.d.» Retrieved [fecha], from www. clad.org.

Comisión Interamericana de Derechos Humanos. «n.d.» Retrieved [fecha], from http://www.cidh.oas.org/DefaultE.htm. Jurisprudencia - Corte Interamericana de Derechos Humanos. «n.d.» Retrieved [fecha], from www.corteidh.or.cr/index.php/jurisprudencia.

Naciones Unidas. «n.d.» Retrieved [fecha], from www.un.org.

Oficina de Alto Comisionado para los Derechos Humanos - Naciones Unidas. «n.d.» Retrieved [fecha], from www. ohchr.org.

Organización de Estados Americanos. «n.d.» Retrieved [fecha], from www.oas.org.

Eduardo Munera, Jose-Luis Poza-Lujan, Juan-Luis PosadasYagüe, Jose-Enrique Simó-Ten, and Francisco Blanes Integrating Smart Resources in ROS-based systems to distribute services
ADCAIJ: Advances in Distributed Computing and Articial Intelligence Journal Regular Issue, Vol. 6 N. 1 (2017), 21-29 eISSN: 2255-2863 - http://adcaij.usal.es (c) Ediciones Universidad de Salamanca - CC BY-NC-ND 
